\title{
Effects of Organochlorine Insecticides on Bacterial Growth, Respiration and Viability
}

\author{
By P. W. TRUDGILL, R. WIDDUS* AND J. S. REES \\ Department of Biochemistry and Agricultural Biochemistry \\ University College of Wales, Aberystwyth, SY23 3 DD
}

(Accepted for publication 29 July 197I)

\begin{abstract}
SUMMARY
The growth of a range of Gram-positive bacteria was inhibited by organochlorine insecticides while that of Gram-negative organisms was unaffected. Growing cultures of Bacillus subtilis (ATCC 9372) treated with 20 p.p.m. technical chlordane ceased to grow and showed a decline in viable count and respiration rate, both being eliminated after about $3 \mathrm{~h}$. A delayed release of incorporated L-[U- $\left.{ }^{14} \mathrm{C}\right]$ leucine and L-malate dehydrogenase occurred concomitant with a fall of $E_{580}$. It is suggested that these phenomena are a result of disruption of membraneassociated metabolism, including electron transport and cell wall biosynthesis, which leads to cell lysis. No effect on these parameters occurred with growing cultures of Escherichia coli (ATCC 8739). The chlordane sensitivity of succinate oxidation by sphaeroplasts of $E$. coli indicates that the intact cell wall prevents penetration of pesticide to sensitive sites within the walls of Gram-negative bacteria.
\end{abstract}

\section{INTRODUCTION}

The long-term persistence of organochlorine insecticides (Alexander, I968; Kearney, Plimmer \& Helling, 1969) is an indication of their resistance to degradation by soil microorganisms. Limited slow modifications of cyclodiene insecticides in the biosphere have been reported (Korte, Ludwig \& Vogel, I962; Lichtenstein, Schulz \& Cowley, 1963; Korte, 1967; Matsumura \& Boush, 1967, I968; Tu, Miles \& Harris, I968; MacRae, Raghu \& Bautista, I969).

Because of their extended persistence, slow rate of decomposition and the fact that the bulk of any insecticide application almost invariably reaches the soil, it is desirable that actual or potential effects upon the soil microflora be investigated. Reported results of experiments, in which growth and metabolic activity of soil bacteria in situ has been investigated following organochlorine insecticide application, range from descriptions of increased activity (Fletcher \& Bollen, I954; Sinha, I96I) or of a total lack of effect (Eno \& Everett, I958; Martin, Harding, Cannell \& Anderson, I959; Shaw \& Robinson, I960) to inhibition of growth and metabolic activity (Bollen, Morrison \& Crowell, I954a, $b$; Sinha, I96I ; MacRae, Raghu \& Castro, 1967; Pramer \& Bartha, 1968).

More consistent results have been obtained with pure cultures of micro-organisms growing on synthetic media. Gray (I954) found that, of fifty species of heterotrophic bacteria incubated on nutrient agar, growth of 37 was inhibited by $\gamma$-hexachlorocyclohexane at 250 p.p.m. Gray \& Rogers (I955) observed the growth only of Gram-negative organisms when mixed cultures from soil samples were incubated on nutrient agar with $\gamma$-hexachloro-

* Present address : Centre for Theoretical Biology, State University at Buffalo, New York I4226, U.S.A.

Vol. 68, No. 3, was issued 3 January 197 I. 
cyclohexane as a surface film (50 $\mathrm{g}$. $\left./ \mathrm{cm} .{ }^{2}\right)$. Duda (1958) found that chlordane and hexachlorocyclohexane incorporated into nutrient agar at 500 and 1000 p.p.m. inhibited the growth of Bacillus mycoides, Bacillus subtilis, Sarcina lutea and Streptomyces griseus while the growth of Escherichia coli and other Gram-negative organisms was unaffected. Collins \& Langlois (I968) demonstrated that addition of 50 p.p.m. heptachlor to liquid culture media inhibited the growth of Staphylococcus aureus while growth of Pseudomonas fluorescens was unaffected. Lyr (1969) has reported the inhibition of growth of B. subtilis by 30 p.p.m. $\delta$-hexachlorocyclohexane.

We now extend these observations, demonstrate some of the phenomena associated with toxicity towards Gram-positive bacteria and indicate the characteristic which confers immunity upon Gram-negative organisms. A preliminary report of some of this data has already appeared (Trudgill \& Widdus, 1970).

\section{METHODS}

Organisms. The sources of all the bacteria used are shown in Table I. Stock cultures were maintained on nutrient agar slopes, with the exception of Streptococcus faecalis for which the nutrient agar was fortified with $3 \%(w / v)$ D-glucose.

Growth media. Organisms were grown on nutrient agar solid media or in liquid culture on nutrient broth (Oxoid Ltd, London) when typically $100 \mathrm{ml}$. of medium in a $250 \mathrm{ml}$. Erlenmeyer was shaken at $30^{\circ}$ and $200 \mathrm{rev} . / \mathrm{min}$. on a New Brunswick gyrotary shaker (New Brunswick Scientific Co., New Brunswick, New Jersey, U.S.A.). For growth of Streptococcus facecalis $\mathrm{D}$-glucose, $3 \%(\mathrm{w} / \mathrm{v})$, was incorporated into the medium.

Table I. Sources of the bacteria

\begin{tabular}{|c|c|}
\hline \multicolumn{2}{|c|}{ Gram-positive bacteria } \\
\hline Bacillus cereus & Laboratory strain isolated from milk \\
\hline B. megaterium & NCTC 9848 \\
\hline B. subtilis & ATCC 9372 \\
\hline Corynebacterium sp. TI & Kay, Conrad \& Gunsalus ( I962) \\
\hline Microbacterium flavum & NCIB 8707 \\
\hline Micrococcus lysodeikticus & NCIB 9278 \\
\hline Nocardia sp. A & Laboratory strain isolated from soil \\
\hline Nocardia sp. в & Laboratory strain isolated from soil \\
\hline Sarcina lutea & NCIB 8553 \\
\hline Staphylococcus albus & Laboratory strain \\
\hline Staphylococcus aureus & Laboratory strain \\
\hline Streptococcus faecalis & NCIB $866 \mathrm{I}$ \\
\hline Streptomyces antibioticus & NCIB 8504 \\
\hline \multicolumn{2}{|c|}{ Gram-variable bacteria } \\
\hline $\begin{array}{l}\text { Arthrobacter simplex } \\
\text { Pseudomonas iodinum }\end{array}$ & $\begin{array}{l}\text { NCIB } 8929 \\
\text { NCIB } 8 \text { I } 79 \text { Wilkinson (I968) }\end{array}$ \\
\hline \multicolumn{2}{|c|}{ Gram-negative bacteria } \\
\hline $\begin{array}{l}\text { Achromobacter butyri } \\
\text { Achromobacter } \mathrm{sp} \text {. PC } 4 \\
\text { Escherichia coli } \\
\text { Klebsiella aerogenes } \\
\text { Pseudomonas acidivorans } \\
\text { P. aureofaciens } \\
\text { P. dehalogens } \\
\text { P. fluorescens } \\
\text { P. fluorescens } \\
\text { P. multivorans } \\
\text { P. putida }\end{array}$ & $\begin{array}{l}\text { NCIB } 9404 \\
\text { (Dagley, Chapman \& Libson, 1963) } \\
\text { ATCC } 8739 \\
\text { Laboratory strain } \\
\text { ATCC } 17454 \\
\text { NCIB } 9030 \\
\text { NCIB } 906 \text { I } \\
\text { (Trudgill \& Widdus, I966) } \\
\text { NCIB } 9392 \\
\text { NCIB } 9092 \\
\text { (Trudgill \& Widdus, I966) }\end{array}$ \\
\hline
\end{tabular}


Measurement of bacterial growth. Bacterial growth was monitored at $580 \mathrm{~nm}$. with an Hitachi Perkin-Elmer model 139 spectrophotometer (Hitachi Ltd, Tokyo). Where necessary dilutions of culture samples were assayed so that the measured extinction did not exceed 0.7 .

Viable cell counts. Viable cells in growing and experimental cultures were estimated, as colony-forming units, by appropriate serial dilution followed by sample plating on nutrient agar.

Measurement of respiration. Oxygen uptake by bacterial suspensions or sphaeroplasts was determined using a Clark-type oxygen electrode in an agitated and thermostatically controlled reaction vessel (Oxygen Monitor, model 53; Yellow Springs Instrument Co., Inc., Yellow Springs, Ohio, U.S.A.).

Preparation of sphaeroplasts. Sphaeroplasts of Escherichia coli in which cell wall removal was not complete (Martin, I963; Salton, 1964) were prepared by the method of Lederberg (1956) in which benzyl penicillin, IOo units/ml., was added to growing cultures in the presence of sucrose. Sphaeroplasts were collected by centrifuging at $9000 \mathrm{~g}$ and $4^{\circ}$ for $\mathrm{I} \mathrm{h}$. and resus-

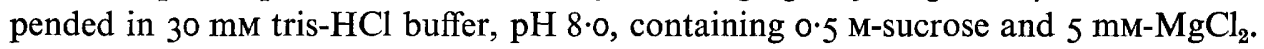

Organochlorine insecticides. Technical grade chlordane (I,2,4,5,6,7,8,8-octachloro$3 a, 4,7,7 a$-tetrahydro-4,7-methanoindane), technical grade endrin (I,2,3,4, 10, 10-hexachloro6, 7-epoxy-I, 4, 4a,5,6,7,8,8 a-octahydro-endo-I, 4-endo,5,8-dimethanonaphthalene), $\gamma$-hexachlorocyclohexane (I,2,3,4,5,6-hexachlorocyclohexane) and telodrin (I,3,4,5,6,7,8,8 aoctachloro-1,3,3a,4,7,7a-hexahydro-4,7-methanoisobenzofuran) were donated by Lankro Chemial Co., Eccles, Manchester. Technical grade chlordane, analytical grade $\alpha$-chlordane, analytical grade $\gamma$-chlordane, technical grade bandane $(4,5,6,7,8,8 a$-hexachloro- $3 a, 4,7,7 a$ tetrahydro-4,7-methanoindane) and technical grade heptachlor (I,4,5,6,7,8,8 $a$-heptachloro$3 a, 4,7,7 a$-tetrahydro-4,7-methanoindane) were donated by Velsicol Chemical Corp., Chicago, U.S.A. Technical grade aldrin (I,2,3,4,10, 10-hexachloro- $\mathrm{I}, 4,4 a, 5,8,8 a$-hexahydroendo-I,4-exo-5,8-dimethanonaphthalene), technical grade dieldrin (I,2,3,4,10, I0-hexachloro6,7-epoxy-I,4,4a,5,6,7,8,8a-octahydro-endo-I,4-exo-5,8-dimethanonaphthalene) and technical grade thiodan $(6,7,8,9,10,10 a$-hexachloro-I , 5,5 $a, 6,9,9 a$-hexahydro-6,9-methano-2-4,3benzodioxathiopen-3-oxide) were donated by Shell Research Ltd, Sittingbourne, Kent. DDT [2,2-bis ( $p$-chlorophenyl)-I,I, I-trichloro-ethane] was obtained from Kodak Ltd, London.

Gas-liquid chromatography of chlordane. Technical chlordane was analysed with a PerkinElmer F. I I Gas Chromatograph (Perkin-Elmer Ltd, Beaconsfield, Buckinghamshire) using a stainless steel column ( $\mathrm{I} .5 \mathrm{~m}$. long and $2 \mathrm{~mm}$. internal diameter) packed with $5 \%$ S.E. 30 on Chromosorb W, 60 to 80 mesh, acid washed and treated with dimethyldichlorosilane. Argon was employed as carrier gas and the detector was of the hydrogen flame ionization type.

Addition of organochlorine insecticides to aqueous media. Because of the near complete insolubility of these compounds in aqueous solution our methods of administration aimed at producing finely divided suspensions, without resorting to the use of emulsifying or carrier agents which are frequently used commercially. Typically, additions to experimental systems were made in acetone solution. Final pesticide concentrations of 2 to I000 p.p.m. could be achieved without allowing the acetone concentration to exceed $0.5 \%(\mathrm{v} / \mathrm{v})$. Applications to solid media were made by allowing an appropriate volume of an acetone or light petroleum (b.p. 40 to $60^{\circ}$ ) solution of the pesticide to evaporate on the surface of the medium leaving behind a thin film of the compound.

Radioactive materials and their assay. $\mathrm{L}-\left[\mathrm{U}-{ }^{14} \mathrm{C}\right]$ leucine was obtained from the Radiochemical Centre, Amersham, Buckinghamshire. Incorporation of radioactive leucine into bacterial cultures was estimated by aseptically withdrawing samples from the culture, 
followed by collection of the cells on Oxoid membrane filters (mean pore diameter $0.5 \mu$ ), thorough washing of the filters with deionized water, transfer to planchets, drying and counting on a Nuclear Chicago model 8705 Automatic Gas-Flow Counter.

Enzyme assays. L-Malate:NAD oxidoreductase (ED I . I . I . 37) (L-malate dehydrogenase) activity of Bacillus subtilis was assayed by observing the decrease in $E_{340}$ subsequent to the addition of oxaloacetate ( $2 \mu$ moles) to a $\mathrm{I} \mathrm{cm}$. light path cuvette which contained, in $3 \mathrm{ml}$., the test extract, phosphate buffer ( $\mathrm{pH}_{7} \cdot 1$ ), and $0.5 \mu$ mole of NADH.

\section{RESULTS}

Sensitivity of plate-cultured bacteria to organochlorine insecticides. Technical grade insecticides were applied to nutrient agar plates as surface films $\left(0.5 \mathrm{mg} . / \mathrm{cm} .{ }^{2}\right)$. Plates were inoculated from stock agar slopes and growth assessed visually after 24 and $48 \mathrm{~h}$. (Table 2). Differences in susceptibility to inhibition of growth can be correlated with the Gram-stain reaction. Gram-negative organisms are, almost without exception, resistant while

Table 2. The effects of organochlorine insecticides on bacterial growth

Micro-organism

Bacillus megaterium

B. subtilis

Streptomyces antibioticus

Nocardia sp. B

Corynebacterium sp. T I

$B$. cereus

Nocardia sp. A

Microbacterium flavum

Micrococcus lysodeikticus

Staphylococcus albus

Staphylococcus aureus

Sarcina lutea

Streptococcus faecalis

Arthrobacter simplex

Pseudomonas iodinum

Achromobacter butyri

Achromobacter sp. PC 4

Escherichia coli

Klebsiella aerogenes

$P$. acidivorans

$P$. aureofaciens

$P$. dehalogens

$P$. fluorescens

$P$. fluorescens

$P$. multivorans

P. putida
Insecticide

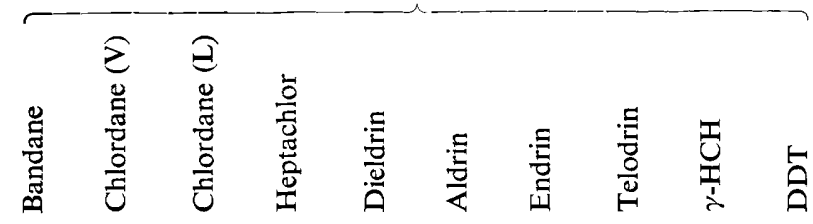

Gram-positive

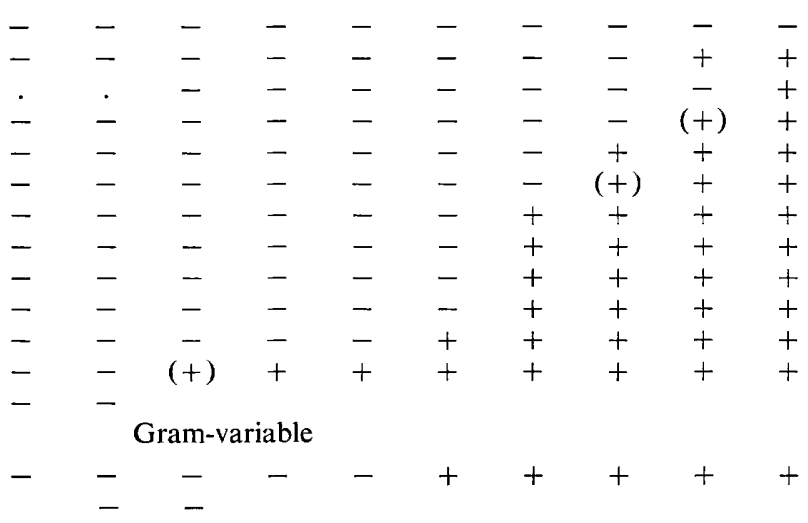

Gram-negative

$\begin{array}{llllllllll}+ & + & + & + & + & + & + & + & + & + \\ + & + & + & + & + & + & + & + & + & + \\ + & + & + & + & + & + & + & + & + & + \\ + & + & + & + & + & + & + & + & + & + \\ + & + & + & + & + & + & + & + & + & + \\ + & + & + & + & + & + & ++ & + & + & + \\ + & + & + & + & + & + & + & + & + & + \\ + & + & + & + & + & + & + & + & + & + \\ + & + & + & + & + & + & + & + & + & + \\ + & + & + & + & + & + & + & + & + & + \\ + & + & + & + & + & ++ & + & + & + & +\end{array}$

+ , Growth not inhibited; $(+)$, growth slightly inhibited; - , growth severely or completely inhibited. 

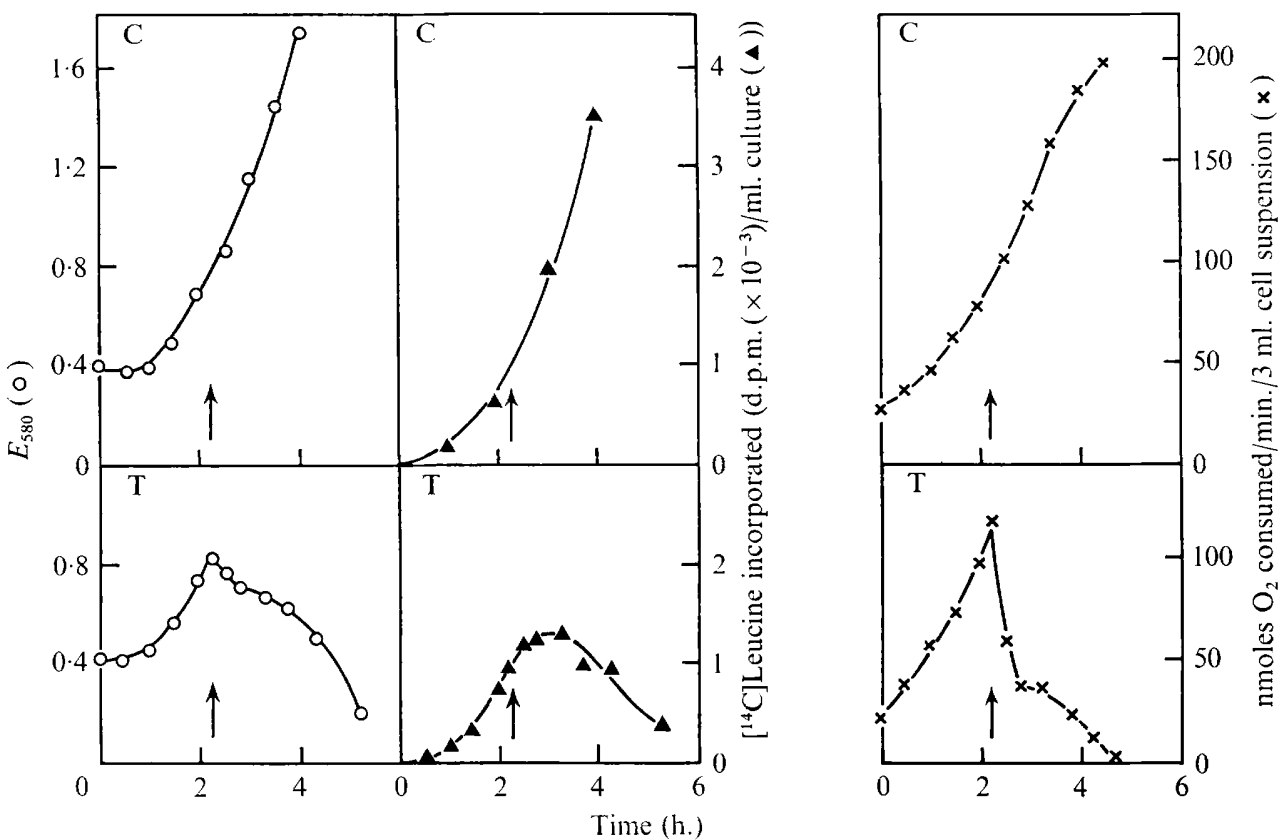

Fig. I. The effect of technical chlordane (20 p.p.m. final concentration), administered in acetone solution, upon the growth $\left(E_{580}\right)$, respiration rate and incorporation of radioactive leucine by Bacillus subtilis growing in nutrient broth. Additions of acetone to control flasks (C) and chlordane in acetone to the test flasks $(\mathrm{T})$ are indicated by the arrows. For details of the techniques employed in measuring radioactive leucine incorporation and respiration see the Methods section.

Table 3. The effects of various concentrations of technical chlordane on bacterial growth

Chlordane (mg./cm. $\left.{ }^{2}\right)$

Micro-organism

Bacillus megaterium

B. subtilis

Corynebacterium sp. T I

B. cereus

Nocardia sp. B

Staphylococcus aureus

Sarcina lutea

Streptococcus faecalis

Achromobacter butyri
Escherichia coli
Klebsiella aerogenes
Pseudomonas acidivorans
$P$. fuorescens
$P$. multivorans
$P$. putida

$\overbrace{\text { I. } 0 \text { O.I }}^{0.01 \quad \text { Vapour* }}$

Gram-positive

$\begin{array}{cccc}- & - & - & - \\ - & - & - & - \\ - & - & - & - \\ - & - & (+) & - \\ - & - & (+) & - \\ - & - & - & - \\ - & - & (+) & - \\ - & - & (+) & -\end{array}$

Gram-negative

$\begin{array}{llll}+ & + & + & + \\ + & + & + & + \\ + & + & + & + \\ + & + & + & + \\ + & + & + & + \\ + & + & + & + \\ + & + & + & +\end{array}$

+ , Growth not inhibited; $(+)$, growth slightly inhibited; - , growth severely or completely inhibited.

* A drop of chlordane was placed in the lid of each inverted Petri dish. 
Gram-positive organisms show a variation of susceptibility. Bacillus species are the most sensitive, judged by the range of insecticides which inhibit their growth, while staphylococci and sarcinas are much less so. The two Gram-variable organisms studied probably occupy an intermediate position. All the cyclodiene insecticides are of similar potency with the exception of endrin and telodrin. $\gamma$-Hexachlorocyclohexane and DDT inhibited growth of only a few of the Gram-positive organisms under investigation.

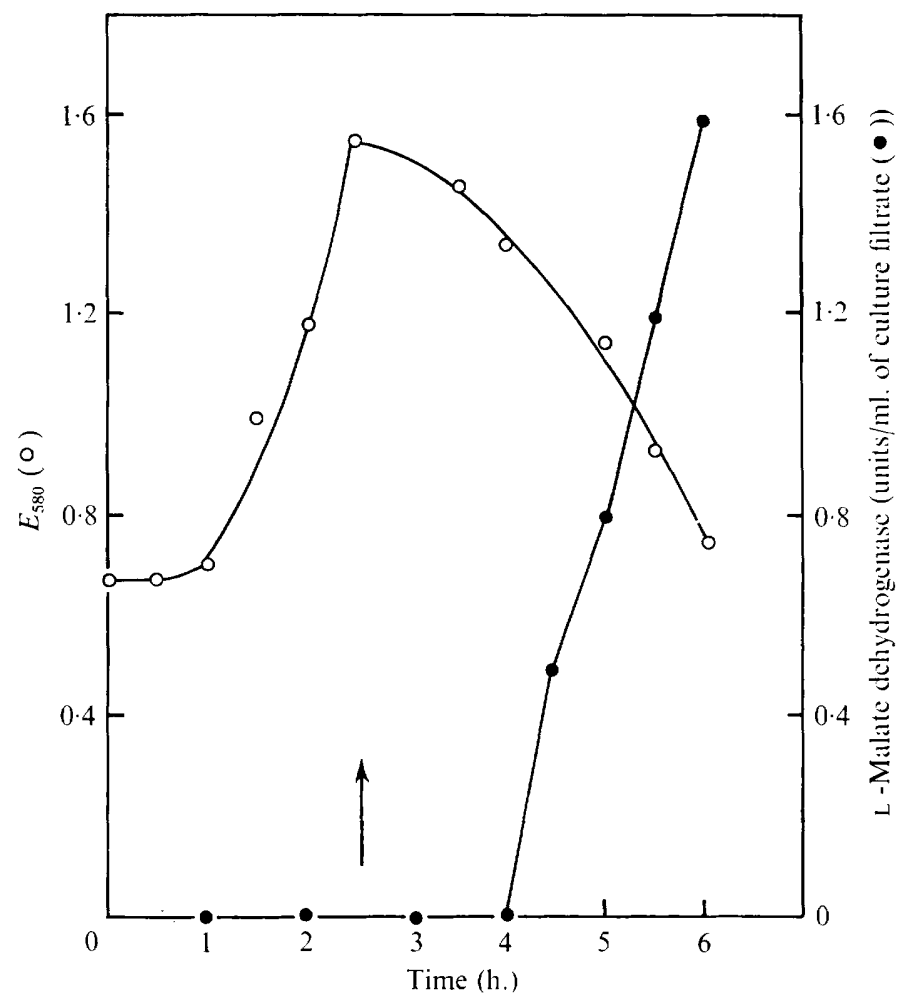

Fig. 2. The effect of technical chlordane (20 p.p.m. final concentration), administered in acetone solution, on a growing culture of Bacillus subtilis showing the delayed release of malate dehydrogenase from the cells, which is associated with the fall in $E_{580}$. For details of the malate dehydrogenase assay see the Methods section.

Sensitivity of plate-cultured bacteria to a range of technical chlordane concentrations. The effects of technical chlordane further emphasizes the relative sensitivity of Gram-positive organisms (Table 3). Growth of all Gram-positive bacteria tested was inhibited at concentrations 10o-fold less than those shown to have no detectable effect upon Gram-negative organisms.

For a more detailed investigation of these phenomena Bacillus subtilis (ATCC 9372) and Escherichia coli (ATCC 8739) were selected as representative susceptible and resistant strains while technical chlordane was chosen as the test compound because, being a syrup, it is relatively easily dispersed in aqueous media.

Effects of technical chlordane on the growth and respiration of Bacillus subtilis. The growth of $B$. subtilis on nutrient broth containing L- $\left[\mathrm{U}-{ }^{14} \mathrm{C}\right]$ leucine in shake culture was completely inhibited by chlordane at 20 p.p.m. Respiration virtually ceased $3 \mathrm{~h}$. after administration of 


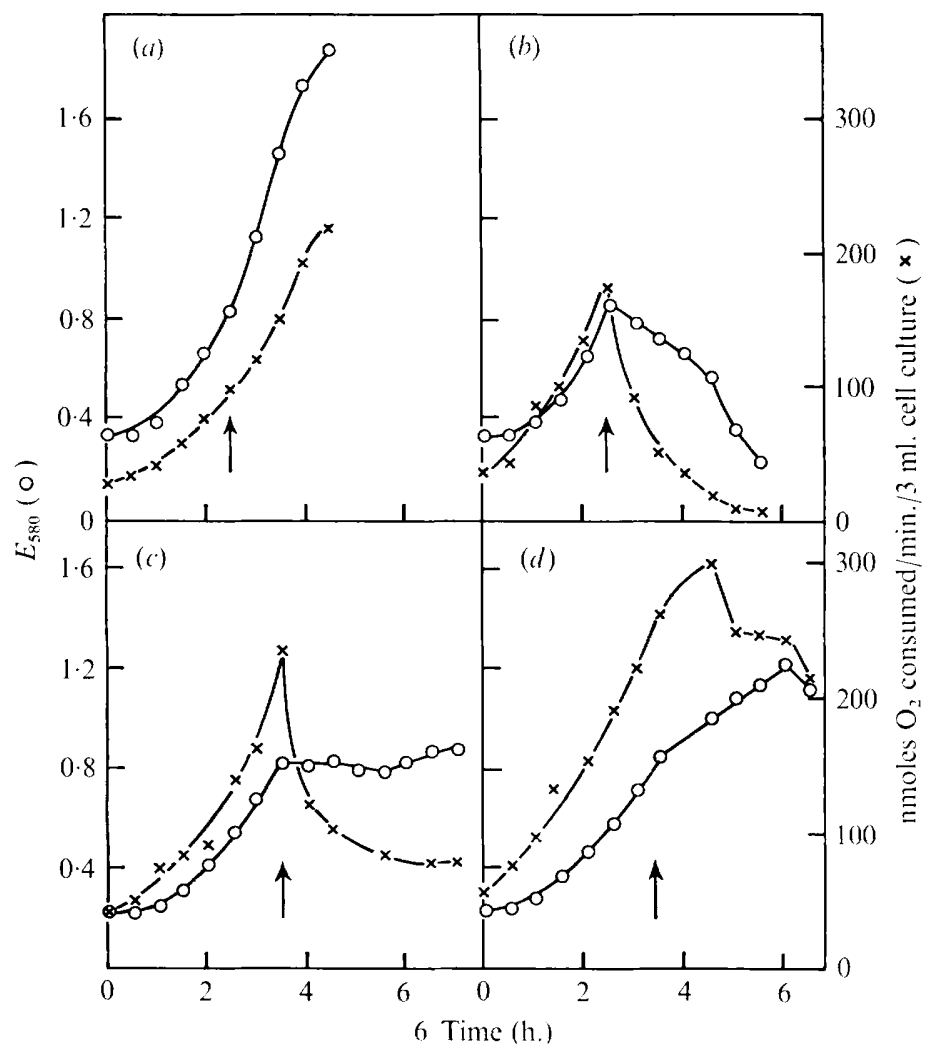

Fig. 3. The effects of various levels of technical chlordane on the growth $\left(E_{580}\right)$ and respiration of Bacillus subtilis in nutrient broth culture. Additions of acetone to a control culture, Fig. 3(a); 20 p.p.m. chlordane, Fig. $3(b)$; Io p.p.m. chlordane, Fig. $3(c)$; and 5 p.p.m. chlordane, Fig. $3(d)$ in acetone were made at times indicated by the arrows.

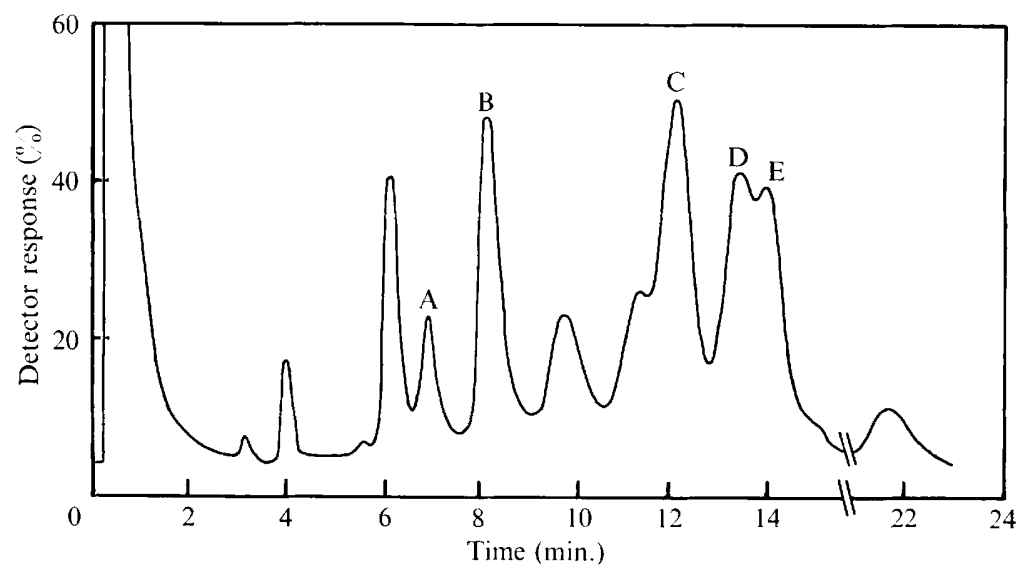

Fig. 4. Gas chromatographic analysis of technical grade chlordane (10 $\mu \mathrm{g}$.) was performed on a column of silicone gum rubber (S.E.-30) supported on Chromosorb W (60 to 80 mesh) at a temperature of $200^{\circ}$ with other conditions as described in the Methods section. Peaks, identified by comparison with authentic pure compounds or from appropriate literature references (see text) are: A, heptachlor; B, bandane, C, $\gamma$-chlordane; D, $\alpha$-chlordane; E, nonachlor $(1,2,3,4,5,6,7,8,8$ nonachloro-3a, 4, 7, $7 a$-tetrahydro-4, 7-methanoindane). 
chlordane (Fig. I) and the rapid fall in $E_{580}$ coupled with the release of [ ${ }^{14} \mathrm{C}$-labelled material from the bacteria suggest that marked changes in cell permeability or even cell lysis may be occurring. The leakage of L-malate dehydrogenase from the cells which commences, following a time lag of $\mathrm{I} \frac{1}{2} \mathrm{~h}$., after administration of chlordane and is associated with the rapid fall in $E_{580}$, supports this view (Fig. 2). No viable bacteria remained $3 \mathrm{~h}$. after addition of 20 p.p.m. chlordane.

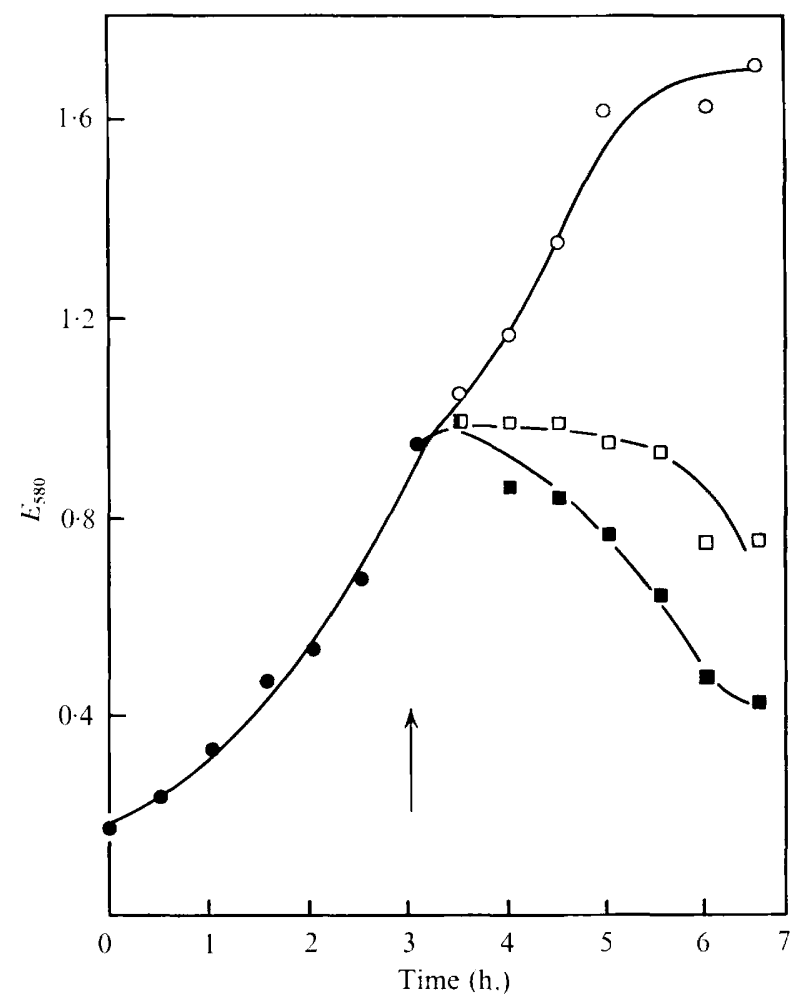

Fig. 5. Effect of pure isomers of chlordane upon the growth $\left(E_{580}\right)$ of Bacillus subtilis in nutrient broth. Additions, indicated by the arrows, were made to parallel cultures $(0)$ as follows: $(O)$, acetone, as a control; $\square, \alpha$-chlordane; $\square, \gamma$-chlordane. The final concentration of both chlordane isomers was 20 p.p.m.

While essentially similar results were obtained with Ioo p.p.m. chlordane, Io and 5 p.p.m. had progressively decreasing effects upon growth and respiration (Fig. 3).

When exponential phase broth-grown bacteria were harvested, thoroughly washed and resuspended in phosphate buffer, $\mathrm{pH} 7 \cdot \mathrm{I}$, in the absence of a nitrogen source but with $22 \mathrm{mM}$-glucose present to suppress sporulation, decrease in $E_{580}$ (initial value I $\cdot 0$ ) and release of L-malate dehydrogenase did not occur on addition of 20 p.p.m. technical chlordane. Respiration was progressively inhibited, $50 \%$ inhibition being achieved $2 \mathrm{~h}$. after administration of chlordane.

Technical chlordane is a complex mixture of closely related compounds (Fig. 4) a number of which have been identified in the sample used either by reference to retention times of analytical samples or to gas chromatography data obtained by other workers (Bevenue \& Yeo, 1969). Though it is appreciated that technical chlordane is the material used for pest 
control purposes it seemed desirable to see whether or not the pure $\alpha$ and $\gamma$ isomers are themselves actively antibacterial. A very similar pattern of growth inhibition is obtained when the pure isomers are added to growing cultures of Bacillus subtilis (Fig. 5). Therefore the cyclodiene itself is an effective antibacterial compound and the phenomena observed when the technical material is used are not due to some chemically unrelated impurity present.

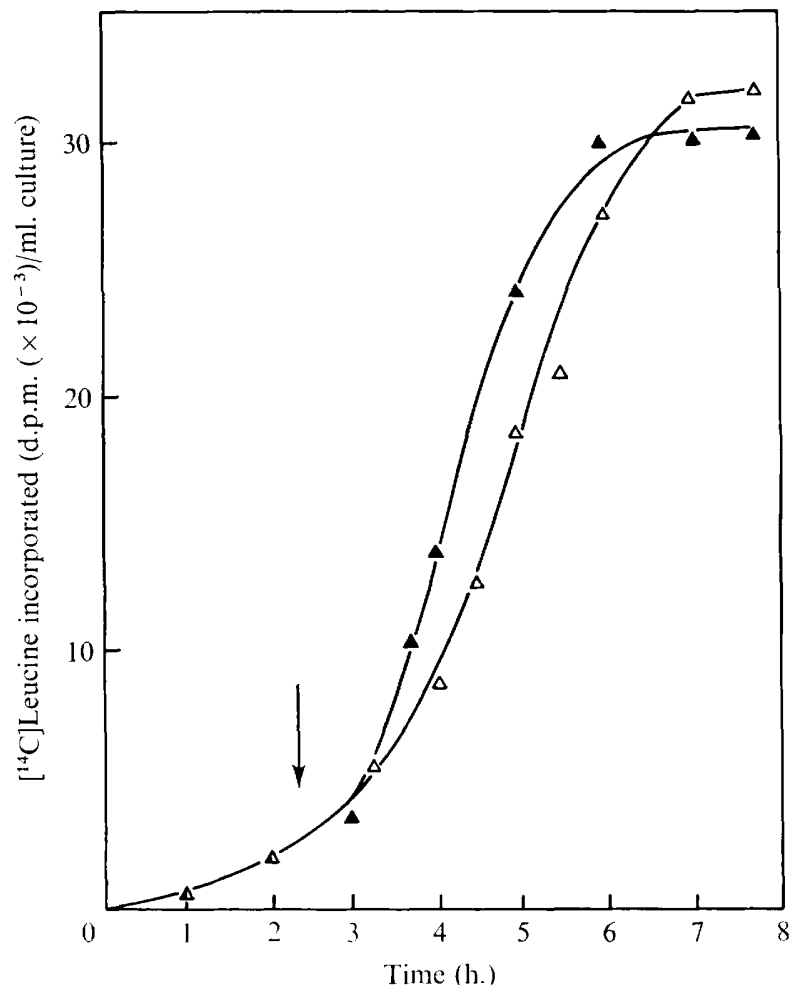

Fig. 6. Effect of technical chlordane upon the incorporation of radioactive leucine by Escherichia coli growing aerobically in nutrient broth. Additions, indicated by the arrows, were made to parallel cultures as follows: $\triangle$, acetone as a control; $\boldsymbol{\Delta}$, technical chlordane in acetone, final concentration IOOO p.p.m.

Table 4. The effect of technical chlordane on succinate oxidation by sphaeroplasts of Escherichia coli

Oxygen monitor vessels contained, in $3 \mathrm{ml}$., $0.03 \mathrm{M}$-tris buffer $(\mathrm{pH} 8.0$ ) with $0.5 \mathrm{M}$-sucrose and $5 \mathrm{mM}^{-} \mathrm{MgCl}_{2}$, benzyl penicillin sphaeroplasts obtained from $10 \mathrm{mg}$. dry wt of $E$. coli and $17 \mathrm{~mm}-$ disodium succinate. Reactions were carried out at $30^{\circ}$ with omissions or additions as indicated.

$\begin{array}{cc}\begin{array}{c}\text { Oxygen con- } \\ \text { sumed } \\ \text { (nmoles/min.) }\end{array} & \begin{array}{c}\text { Inhibition } \\ (\%)\end{array} \\ 14.6 & - \\ 58.5 & - \\ 50.5 & 12 \\ 20.4 & 74.5 \\ 20.5 & 74.0\end{array}$

Succinate omitted

Complete system

Acetone added ( $15 \mu \mathrm{l})$

*Chlordane added (20 p.p.m.)

Chlordane added (100 p.p.m.)

* Additions of chlordane were made in $15 \mu \mathrm{l}$. of acetone. 
Such an observation does not, of course, alter the likelihood that the bandane, heptachlor and other components of technical chlordane have antibacterial activity.

Effects of technical chlordane on the growth and respiration of Escherichia coli. Neither the growth of $E$. coli (ATCC 8739) in nutrient broth nor incorporation of $\mathrm{L}-\left[\mathrm{U}-{ }^{14} \mathrm{C}\right]$ leucine by growing cultures is inhibited by technical chlordane at concentrations up to I000 p.p.m. (Fig. 6), thus confirming the resistance of Gram-negative organisms. Respiration of whole organisms was not inhibited by chlordane concentrations up to and including 660 p.p.m.

Benzyl penicillin-induced sphaeroplasts of Escherichia coli (Lederberg, I956) display a chlordane sensitive succinate respiration (Table 4) though whole organisms suspended in the same sucrose-buffer system are still completely resistant, implying that the complex wall of this organism acts as an effective barrier to chlordane penetration.

\section{DISCUSSION}

The inhibition of growth of Gram-positive bacteria by organochlorine insecticides and the lack of effect upon Gram-negative organisms (Tables I and 2) is a general extension of the observations of Gray \& Rogers (I955), Duda (I958) and Lyr (I969).

Within the cyclodiene group the syrupy preparations, technical chlordane and technical bandane, show a wider range of toxicity than, for example, the slightly more polar and crystalline telodrin (Table 2 ). Whether this is significant or simply a reflexion of the greater ease with which the syrups form a continuous film on an agar surface is not clear. Toxicity of the lowest concentration used on agar plates $\left(0.01 \mathrm{mg} . / \mathrm{cm} .{ }^{2}\right)$ is difficult to relate to concentrations in liquid medium used in later experiments, but it does clearly demonstrate the variation in response of Gram-positive bacteria, Sarcina lutea and Streptotoccus faecalis being significantly less sensitive to technical chlordane than Bacillus subtilis (Table 3).

Addition of technical chlordane to a growing culture of Bacillus subtilis causes several changes the most rapid of which is a marked decrease in respiration rate, probably a result of attraction of the hydrophobic pesticide molecules to the lipid core of the lipoprotein membrane with a consequent disruption of its electron transport ability. This view is reinforced by the lack of effect of technical chlordane upon the activity of soluble cytoplasmic enzymes such as L-malate dehydrogenase. Less rapid, but equally dramatic loss of incorporated $\left[{ }^{14} \mathrm{C}\right]$ leucine and L-malate dehydrogenase from the bacteria (Fig. 2) occurs together with a fall in $E_{580}$ and loss of viability. Since such observations all indicate eventual cell lysis following inhibition of respiration a plausible explanation of this is worthy of consideration.

If we take the rapid crippling of respiration as an indication of impairment of membrane function then it is likely that a number of essential membrane-dependent activities are also disrupted. This may include such activities as protein synthesis and, interestingly, cell wall biosynthesis since Anderson, Matsuhashi, Haskin \& Strominger (1965) have suggested that murein precursors formed within the cell are attached to lipid moieties in the membrane for translocation to the exterior. Such a chlordane-induced disruption of cell wall biosynthesis may trigger cell lysis, a view reinforced by the observation that treatment of resting Bacillus subtilis suspensions (in $22 \mathrm{~mm}$-glucose to suppress sporulation) with chlordane at 20 p.p.m. fails to promote a decrease in $E_{580}$ or leakage of L-malate dehydrogenase.

Koch $(1969 a, b)$ has reported inhibition of both the $\mathrm{Na}^{+} / \mathrm{K}^{+}$dependent transport ATPase and the $\mathrm{Mg}^{2+}$ dependent oxidative phosphorylation ATPase of rat brain homogenates by aldrin, chlordane, dieldrin, $\gamma$-hexachlorocyclohexane and DDT. Koch, Cutkamp \& Do (1969) and Patil, Matsumura \& Bratkowski (I969) have reported similar observations with insect tissues. Since bacterial ATPase enzymes are known to be associated with the bacterial 
cell membrane it is possible that cyclodiene insecticides may interfere with the functioning of these enzymes interrupting transport and oxidative phosphorylation and disturbing permeability barriers. Since Streptococcus faecalis (NCIB 866I) possesses no membrane-bound cytochrome electron transport chain and is a lactate producing fermenter with substrate-level phosphorylation, electron transport cannot be a target site in this organism. Perhaps this is reflected in its decreased sensitivity to technical chlordane, relative to Bacillus subtilis (Table 3), the pesticide still being lethal because of the disruption of the other membrane associated phenomena that have been discussed.

The demonstration that Gram-positive bacteria obtained from culture collections and grown under laboratory conditions are sensitive to organochlorine pesticides at concentrations roughly equivalent to those found in the soil (Stringer \& Pickard, 1963) is not of itself proof that agricultural application of these compounds will result in a selection of resistant Gram-negative organisms. However, as an indication that this may indeed occur it has been shown by Kokke (1970) that the proportion of DDT-resistant bacteria is markedly elevated in DDT-containing environments. Cyclodiene insecticide-resistant Gram-positive strains do exist as illustrated by the reported contamination of aldrin samples by Bacillus cereus and Bacillus subtilis (Fletcher \& Bollen, 1954).

To test the theory that the cell walls of resistant Gram-positive organisms act as a barrier to organochlorine insecticides it is not strictly necessary to know first the primary site, if any, of action of the compound. Any activity internal to the wall and sensitive to the pesticide can serve as an indicator. Succinoxidase of Escherichia coli (ATCC 8739) is just such an indicator (Trudgill \& Widdus, 1970) and is known to be membrane bound (Gel'man, Lukoyanova \& Ostrovski, 1967). Since modification of cell wall permeability of $E$. coli by penicillin renders succinoxidase sensitive to technical chlordane (Table 4) a cell wall dependent resistance of Gram-negative organisms to cyclodiene pesticides is postulated. Other known instances where the cell walls of Gram-negative organisms prevent access of antibacterial compounds occur with hexachlorophene (Joswick, I96I), tetrachlorosalicylanilide (Hamilton, I968) and anacardic acids (Gellerman, Walsh, Werner \& Schlenk, I969). While it can be appreciated that the more complex cell wall of a Gram-negative organism may be able to act as a barrier to cyclodiene penetration it is also, and perhaps paradoxically, interesting that in general Gram-negative cell walls contain more lipid than those of Gram-positive organisms and so might be expected to attract these very hydrophobic compounds. Indeed, such a suggestion is supported by observations of Chacko \& Lockwood (1967) who demonstrated that Agrobacterium tumefaciens was much more effective at accumulating dieldrin and DDT than was Bacillus subtilis.

Factors which confer resistance to other antibacterial compounds upon some organisms, such as the development of detoxifying enzymes or absence of a specific target site are probably not relevant in the case of cylodiene insecticides. In the first place the rapid death of Gram-positive bacteria, as judged by the decline in respiration as well as viability, makes it unlikely that a resistant Gram-negative organism could produce a detoxifying enzyme rapidly enough to ward off the effects of technical chlordane. A view reinforced by the known very slow metabolic conversion of the compound by bacteria and the failure of chlordane to inhibit growth of Escherichia coli even at concentrations as high as I000 p.p.m. Though the possibility of a specific target site being absent from Gram-negative bacteria and thus rendering them immune has not been categorically excluded it is unlikely in view of the relatively high concentrations of chlordane needed to inhibit Gram-positive bacterial growth, about $\mathrm{I} \cdot 5 \times 10^{7}$ molecules/organism added to the growth medium. Though we have not yet established what fraction of the added chlordane is taken up by the cells a useful comparison 
is provided by the nonspecific physicochemically membrane-active antibacterial compounds such as monochlorophenoxysalicylanilide, $7 \cdot 2 \times 10^{5}$ molecules of which have to be taken up by each cell of Staphylococcus aureus to achieve bacteriostasis (Hamilton, 1968). By contrast antibacterial compounds for which specific target sites have been demonstrated exert their effects at uptake levels several orders of magnitude lower than that observed with monochlorophenoxysalicylanilide. The inference we draw from this is that chlordane may exert a relatively non-specific but lethal 'swamping effect' which deforms the structural integrity of the cell and would, but for the barrier action of the cell wall, have the same effects upon $E$. coli as are observed with Bacillus subtilis; the respiratory sensitivity of E. coli sphaeroplasts being an indication of this.

We wish to thank the Lankro Chemical Co., Shell Research Ltd, and the Velsicol Chemical Corp. for generously supplying us with organochlorine insecticides and the Science Research Council for supporting one of us (R. W.) with a studentship during the course of this work.

\section{REFERENCES}

AleXANDer, M. (1968). In Ecology of Soil Bacteria, pp. 270-284. Edited by T. R. G. Gray \& D. Parkinson. Liverpool: Liverpool University Press.

Anderson, J. S., Matsuhashi, M., Haskin, M. A. \& Strominger, J. L. (1965). Lipid-phosphoacetylmuramyl-pentapeptide and lipid-phosphodisaccharide-pentapeptide: presumed membrane transport intermediates in cell wall synthesis. Proceedings of the National Academy of Sciences of the United States of America 53, 88I-889.

BevenUe, A. \& YeO, C. Y. (1969). Gas chromatographic characteristics of chlordane. Journal of Chromatography 42, 45-52.

Bollen, W. B., Morrison, H. E. \& Crowell, H. H. (1954a). Effect of field treatments of insecticides on numbers of bacteria, Streptomyces and molds in the soil. Journal of Economic Entomology 47, 302-306.

Bollen, W. B., Morrison, H. E. \& Crowell, H. H. (I954 $b$ ). Effect of field and laboratory treatments with BHC and DDT on nitrogen transformations and soil respiration. Journal of Economic Entomology 47, 307-312.

Cнаско, C. I. \& Lockwoon, J. L. (1967). Accumulation of DDT and dieldrin by micro-organisms. Canadian Journal of Microbiology 13, I 123-1 I 26.

Collins, J. A. \& LANGLors, B. E. (I968). Effect of DDT, dieldrin and heptachlor on the growth of selected bacteria. Applied Microbiology 16, 799-800.

Dagley, S., Chapman, P. J. \& Gibson, D. T. (1963). Oxidation of $\beta$-phenylpropionic acid by an Achromo-

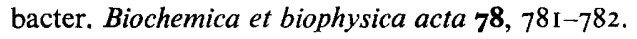

DudA, A. (1958). The effects of hexachlorocyclohexane and chlordane on soil microflora. Acta microbiologica polonica $7,237-244$.

ENo, C. F. \& EveretT, P. H. (1958). Effects of soil applications of Io chlorinated hydrocarbon insecticides on soil microorganisms and the growth of stringless black valentine beans. Proceedings of the Soil Science Society of America 22, 235-238.

Fletcher, D. W. \& Bollen, W. B. (1954). The effects of aldrin on soil microorganisms and some of their activities related to soil fertility. Applied Microbiology 2, 339-354.

Gellerman, J. L., Walsh, N. J., Werner, N. K. \& Schlenk, H. (1969). Antimicrobial effects of anacardic acids. Canadian Journal of Microbiology 15, I219-1223.

Gel'man, N. S., Lukoyanova, M. A. \& OstrovskiI, D. N. (1967). Respiration and Phosphorylation of Bacteria. Edited by G. B. Pinchot. New York: Plenum Press.

GraY, P. H. H. (1954). Effects of benzenehexachloride on soil micro-organisms. Canadian Journal of Botany 32, I-9.

Gray, P. H. H. \& Rogers, C. G. (1955). Effects of benzenehexachloride on soil micro-organisms. Canadian Journal of Microbiology 1, 312-318.

HamiLton, W. A. (1968). The mechanism of the bacteriostatic action of tetrachlorosalicylanilide: a membrane active antibacterial compound. Journal of General Microbiology 50, 44I-458. 
Hugo, W. B. \& Frier, M. (1969). Mode of action of the antibacterial compound dequalinium acetate. Applied Microbiology 17, I $18-127$.

Joswick, H. L. (1961). Mode of action of hexachlorophene. Ph.D. Thesis, University of Michigan.

Kay, J. W. D., Conrad, H. E. \& Gunsalus, I. C. (1962). Camphor degradation: hydroxyintermediate formed by a soil diphtheroid. Bacteriological Proceedings $\mathbf{P}_{3} \mathbf{}$.

Kearney, P. C., Plimmer, J. R. \& Helling, C. S. (I969). Soil chemistry of pesticides. In Kirk-Othmer Encyclopaedia of Chemical Technology, 2nd edn, pp. 515-540. New York: John Wiley.

$\mathrm{KoCH}$, R. B. (I969a). Chlorinated hydrocarbon insecticides: inhibition of rabbit brain ATPase activities. Journal of Neurochemistry 16, 269-27I.

$\mathrm{KoCH}, \mathrm{R}$. B. $(1969 b)$. Inhibition of animal tissue ATPase activities by chlorinated hydrocarbon pesticides. Chemical Biological Interactions I, 199-209.

Kосн, R. B., CutкомP, L. K. \& Do, F. M. (I969). Chlorinated hydrocarbon insecticide inhibition of cockroach and honey bee ATPases. Life Sciences 8, 289-297.

KoKKe, R. (1970). DDT: its action and degradation in bacterial populations. Nature, London 226, 977-978.

KorTE, F. ( I 967). Metabolism of chlorinated insecticides. Proceedings of the IUPAC Commission on Terminal Pesticide Residues, Appendix VI, 38-48.

Korte, F., Ludwig, G. \& Vogel, J. (I962). Umwandlung von Aldrin-[ $\left[{ }^{14} \mathrm{C}\right]$ und Dieldrin-[14C] durch Mikroorganismen, Leberhomogenate und Moskitolarven. Justus Liebigs Annalen der Chemie 656, 135-140.

Lederberg, J. (I956). Bacterial protoplasts induced by penicillin. Proceedings of the National Academy of Sciences of the United States of America 42, 574-577.

Lichtenstein, E. P., Schulz, K. R. \& Cowley, G. T. (1963). Inhibition of the conversion of aldrin to dieldrin in soils with methylenedioxyphenyl synergists. Journal of Economic Entomology 56, 485-489.

LyR, H. (1969). On the mechanism of action of $\delta$-hexachlorocyclohexane. Zeitschrift für Allgemeine Mikrobiologie 9, 197-204.

MacRae, I. C., Raghu, K. \& Bautista, E. M. (1969). Anaerobic degradation of the insecticide lindane by Clostridium sp. Nature, London 221, 859-860.

MacRae, I. C., RaGhU, K. \& Castro, T. F. (1967). Persistence and biodegradation of four common isomers of benzene hexachloride in submerged soils. Journal of Agricultural and Food Chemistry 15, 91 I-9I4.

MARTIN, H. H. (1963). Bacterial protoplasts - a review. Journal of Theoretical Biology 5, I-34.

Martin, J. P., Harding, R. B., Cannell, G. H. \& Anderson, L. D. (i959). Influence of five annual field applications of organic insecticides on soil biological and physical properties. Soil Science 87, 334-338.

Matsumura, F. \& Boush, G. M. (1967). Dieldrin, degradation by soil micro-organisms. Science, New York I56, 959-96I.

Matsumura, F. \& Boush, G. M. (1968). Degradation of insecticides by soil fungus Trichoderma viride. Journal of Economic Entomology 6r, 610-612.

Patil, K. C., Matsumura, F. \& Bratkowski, T. A. (I 969). Brain ATPases of the resistant and susceptible German cockroach. Journal of Economic Entomology 62, I 502-1 503.

Pramer, D. \& Bartha, R. (I968). Respiratory effects and decomposition of some pesticides in soil. In Progress in Soil Biodynamics and Soil Productivity, p. 29. Edited by A. Primavesi. Santa Maria, Brazil: Pallotti.

Salton, M. R. J. (1964). The Bacterial Cell Wall. London: Elsevier.

Shaw, W. M. \& Robinson, W. (1960). Pesticide effects in soils on nitrification and plant growth. Soil Science 90, 320-323.

SINHA, N. S. (196I). Effect of field and laboratory treatment with BHC, chlordane and aldrin on bacterial population and nitrification of soil. Proceedings of the Annual Convention of Sugar Technologists of India 29, 17.

Stringer, A. \& Pickard, J. A. (1963). The DDT content of soil and earth-worms in an apple orchard at Long Ashton. Annual Report of the Long Ashton Agricultural and Horticultural Research Station, pp. I 27-I3I.

Trudgill, P. W. \& Widdus, R. (I966). D-Glucarate catabolism by Pseudomonadaceae and Enterobacteriaceae. Nature, London 2I I, I097-1099.

Trudgill, P. W. \& Widdus, R. (1970). Effects of chlorinated insecticides on metabolic processes in bacteria. Biochemical Journal $\mathbf{1 8}$, 48-49 P.

Tu, C. M., Miles, J. R. W. \& Harris, C. R. (1968). Soil microbial degradation of aldrin. Life Sciences 7, 3II-322.

WiLkinson, S. G. (I968). Studies on the cell walls of Pseudomonas species resistant to ethylenediaminetetraacetic acid. Journal of General Microbiology 54, 195-2 I 3. 